\title{
Structural Unemployment: How Important Are Labour Market Policies and Institutions?
}

\author{
Gordon Betcherman \\ World Bank
}

Les différences de taux de chômage entre les pays de l'OCDE ont souvent été interprétées comme étant la preuve de l'importance des institutions et des politiques de main d'oeuvre. Cet argument est fondé (plus souvent en Europe mais aussi au Canada) sur le fait que les taxes élevées sur le salaire, les réglementations de main d'oeuvre rigides et les ententes syndicales inadaptées augmentent les coûts du travail et que les programmes généreux d'aide sociale réduisent les motivations à travailler. Cet article passe en revue les recherches empiriques internationales qui évaluent les impacts de ces politiques de main d'oeuvre sur le chômage et ensuite considère ces résultats dans un contexte canadien. Les résultats suggèrent que l'effet des différentes institutions et politiques de main d'oeuvre sur le chômage n'est pas aussi simple que l'on ne le pensait. Selon les preuves empiriques et depuis les réformes des 15 dernières années, il est difficile de supporter l'hypothèse que les hauts niveaux de chômage au Canada sont causés principalement par un marché du travail inflexible, ce dernier provenant de nos institutions et de nos politiques. En dernière analyse, une explication crédible du chômage au Canada doit regarder au delà de l'assurance-chômage, des taxes, des syndicats et des lois sur la main d'oeuvre.

The variation in unemployment rates across OECD countries has often been interpreted as clear evidence that labour policies and institutions matter a great deal. The basis of this argument (most frequently applied to European countries but also to Canada) is that high payroll taxes, rigid labour regulations, and unresponsive union contracts inflate the cost of labour and that generous welfare programs reduce work incentives. This paper reviews the international empirical research evaluating the unemployment impacts of these labour policies and then considers the results in the Canadian context. The results suggest that the effect of different labour market policies and institutions on unemployment is by no means as simple as the conventional wisdom suggests. At any rate, after the reforms of the past 15 years, it is hard to argue on the basis of the empirical evidence that relatively high levels of unemployment in Canada are primarily due to labour market inflexibility resulting from our policies and institutions. In the final analysis, a credible explanation for Canada's unemployment record must look beyond unemployment insurance, taxes, unions, and labour law.

$\mathrm{T}$ he wide variation in unemployment rates across Organization for Economic Cooperation and Development (OECD) countries (Table 1) has raised questions about the role of policies and institutions in the labour market. Many policymakers, econo- mists, and employers have interpreted the divergence in unemployment rates between the United States and the major European economies as clear evidence that policies and institutions matter a great deal. This argument essentially makes two points: (i) labour 
TABLE 1

Unemployment Rates, OECD Countries, 1998 Rate and 1986-98 Annual Average

\begin{tabular}{lrr}
\hline & Unemployment Rate, 1998 & Average Unemployment Rate, 1986-98 \\
\hline Australia & 8.1 & 8.5 \\
Austria & 6.4 & 5.4 \\
Belgium & 11.7 & 11.2 \\
Canada & 8.3 & 9.4 \\
Denmark & 6.3 & 9.3 \\
Finland & 11.4 & 9.7 \\
France & 11.8 & 10.8 \\
Germany & 11.2 & 8.5 \\
Ireland & 7.7 & 13.9 \\
Italy & 12.2 & 10.6 \\
Japan & 4.1 & 2.8 \\
Netherlands & 4.2 & 6.6 \\
New Zealand & 7.5 & 7.2 \\
Norway & 3.2 & 4.4 \\
Portugal & 5.0 & 6.0 \\
Spain & 18.8 & 19.7 \\
Sweden & 6.5 & 4.9 \\
Switzerland & 3.9 & 2.6 \\
United Kingdom & 6.2 & 8.5 \\
United States & 4.5 & 6.0 \\
\hline
\end{tabular}

Source: Based on OECD (1999, Table 1.3).

has become too costly in many European countries because of high payroll taxes, rigid hiring and dismissal rules, and collective bargaining arrangements that are not responsive to economic realities. (ii) Work disincentives are too high because of the generosity of the welfare system. The implication of this line of thinking is straightforward: adopt US-style policies and structural unemployment will fall accordingly.

This debate is a highly relevant one in Canada. Unemployment has been the most enduring national concern over the past two decades, a period when the aggregate rate has never dipped below 6.8 percent. So, doing something about it should be high on the agenda. A debate should be possible in a country where a belief in markets and social regulation both exist. Characteristically, this ideological dual- ism has resulted in labour policies and institutions that seem to share elements of both the US and European models - and an unemployment rate that sits in between the two. ${ }^{1}$

In fact, the policy choice is not so simple once the empirical evidence is examined closely. First, many economists have concluded that macroeconomic performance explains a lot more of the unemployment divergence across countries than do differences in how labour markets function. Second, even if you accept that the latter is an important factor, it is not entirely clear how flexible (or inflexible) the Canadian labour market actually is. And, third, the conventional wisdom about the impact of different labour market policies and institutions on unemployment is not so clearly borne out by the 
facts. ${ }^{2}$ Indeed, the argument that flexibility is the key to low unemployment - the main legacy of the OECD Jobs Study (1994) - has in no way been consistently supported by empirical research, including subsequent studies emanating from the OECD.

The first two issues have been addressed by papers in this volume (e.g., Osberg and Lin; and Stanford, respectively). Accordingly, I am going to focus on the third issue and take stock of what empirical researchers have concluded about the relationship between labour market policies and institutions, on the one hand, and unemployment levels, on the other. By "policies," I mean the strategies instituted and enforced by governments that affect labour supply or labour demand. These can be regulatory, in the form of rules governing layoffs, minimum wages, and so on or programmatic, such as unemployment insurance and active labour market programs. "Institutions" refer to established arrangements that affect the determination of wages and working conditions (the extent of collective bargaining, negotiating processes, etc.). History and culture heavily influence these institutions. But public policy matters as well in the sense of defining the framework within which institutions operate.

My review relies primarily on econometric analyses by Nickell and Layard (1997) and Elmeskov, Martin and Scarpetta (1998). Augmenting their findings with related studies, I identify the policies and institutions that have been statistically linked with unemployment trends in OECD countries during the 1980s and 1990s. This literature covers a range of variables including taxes, unemployment insurance, minimum wages, active labour market policies, wage determination institutions, and employment protection legislation.

While reviewing the findings in all of these areas, I will offer a somewhat more extended discussion on employment protection legislation, incorporating the results of new research by the OECD (1999). This focus seems appropriate for a number of reasons. First, in comparison to some other policy areas (e.g., unemployment insurance, taxes), economists have undertaken relatively little analysis on the labour market implications of different approaches to employment protection. One reason for this is the complexity involved in measurement because of the qualitative nature of regulation and its enforcement. These measurement difficulties are aggravated in Canada because rules are not uniform due to shared federal and provincial jurisdiction. Second, the cross-country empirical evidence that is available on employment protection has not been definitive with resulting disagreement about its actual impact on unemployment. Third, employment protection is bound to be near the top of the priority list for labour policymakers in Canada in the next few years. The basic changes that have occurred in the labour market - the growth of services, the expansion of non-standard employment, and so on - call for equally fundamental changes in policy. Although labour codes have been amended in a number of jurisdictions during the 1990s, the "industrial era" model still largely prevails. The next round will need to grapple more fundamentally with these changes and what they mean for regulatory policy in the labour market.

\section{Policies, Institutions, and Structural UNEMPLOYMENT}

Economists have commonly distinguished between structural and cyclical sources of unemployment. While this distinction is not without well-known problems, it is nonetheless an important one for the policymaker. ${ }^{3}$ Why does the unemployment rate in some countries fall as far as 3 or 4 percent in good times while in others it never seems to get below 7 or 8 percent even during an expansion? Why do recessions bring double-digit rates in some countries but not in others? One logical explanation is that low-unemployment countries have policies and institutions that create favourable conditions in the labour market through the pricing and deployment of labour and work incentives. But what are those policies and institutions? 
Recent studies by Nickell and Layard (1997) and Elmeskov, Martin and Scarpetta (1998) are especially germane to addressing this question. Each of these papers examines how which policies and institutions explain variations in unemployment rates among OECD countries over the 1980s and 1990s. While the Nickell and Layard (NL) and Elmeskov, Martin and Scarpetta (EMS) studies are wideranging in their inquiries, one part of each is concerned with estimating the following function:

$$
\mathrm{U}_{i t}=\alpha+\beta_{1} \mathrm{X}_{i t}+\beta_{1} \mathrm{~W}_{i t}+\beta_{2} \mathrm{Z}+\mathrm{v}_{i t}
$$

where $\mathrm{U}_{i t}$ is a measure of the national unemployment for country $i$ in year $t, \mathrm{X}_{i t}$ is a vector of policies and institutions characterizing country $i$ in year $t$, $\mathrm{W}_{i t}$ is a variable characterizing cyclical conditions in $i$ at $t, \mathrm{Z}$ is a vector of other variables incorporated into the models (e.g., country dummies, time period dummies), and $\mathrm{v}_{i t}$ is the error term.

There is considerable detail involved in how NL and EMS actually specify and estimate equation (1) and the interested reader is directed toward the studies themselves. However, four points provide necessary background for our purposes.

First, both studies estimate this equation for a set of OECD countries covering the period from the mid-1980s to the mid-1990s. NL includes 20 countries and EMS includes 19. ${ }^{4}$ EMS uses annual data for the 1983-95 period while NL uses two crosssectional observations representing averages for 1983-88 and 1989-94. ${ }^{5}$

Second, $\mathrm{U}_{i t}$ is calculated as the aggregate unemployment rate in EMS and the $\log$ of the unemployment rate in NL. With a few exceptions, both studies rely on the OECD standardized rate. ${ }^{6}$

Third, while our focus is on the policy and institutional determinants of structural or (in NL's usage) equilibrium unemployment, each includes an independent variable $\left(\mathrm{W}_{i t}\right)$ to account for cyclical effects on the measured unemployment rate. NL uses changes in the inflation rate and EMS uses a measure of the output gap. These variables have highly significant coefficients in all estimations.

The fourth and most important point concerns the policy and institutional variables $\left(\mathrm{X}_{i t}\right)$ that might be expected to affect unemployment levels. There are six relevant categories:

Taxes. The key factor determining the effect of taxes on unemployment (by raising the cost of labour) is whether employers or employees bear the cost. The Canadian research is somewhat mixed here. In the short run, payroll taxes do have a negative impact on employment by raising the cost of labour for employers. However, this effect diminishes over the long run as workers seem to assume much of the burden of the taxes (Di Matteo and Shannon 1995). Blanchard and Wolfers (1999) interpret the international evidence similarly, with the tax effect appearing to operate mainly on wages not unemployment. NL includes both a total tax rate and a payroll tax rate while EMS uses a "tax wedge" variable which measures the difference between the real cost of labour for the employer and the real consumption wage for the worker.

Minimum wages. The issue here is also whether employment is negatively affected by higher labour costs. There is no consensus on this in the economics community. Research by Card and Krueger (1997) found no significant employment effect but critiques of this work (e.g., Welch 1995) and contradictory empirical analysis (e.g., Neumark 1999) have enlivened the debate. Specification of a minimum wage variable is difficult in cross-country analysis because coverage is not uniform and some countries have multiple minimum wages. NL did not include a separate minimum wage variable though it is part of a broader labour standards variable they include in their specification. EMS specified the variable as the ratio of the statutory minimum wage to the average wage.

Income support of the unemployed. The employment effects of unemployment insurance (UI) systems 
have been a subject of great interest for labour economists. ${ }^{7}$ The main issue here is the extent to which UI reduces search intensity for unemployed workers. This depends on the "generosity" of unemployment insurance, including both the level of benefits (measured by the "replacement rate") and by the duration of benefits. NL and EMS use different measures here but both capture the benefit level and duration dimensions.

Active labour market programs. Active labour market programs (ALMPs), which include retraining, employment services (information, counselling, job search), and job creation, are intended to help the unemployed get back to work. Empirical evidence of their impact on unemployment, however, is very limited and tentative in its conclusions. A major technical problem relates to uncertainty regarding the direction of the causal relationship. ALMPs can be hypothesized to reduce unemployment, but high unemployment is likely to result in increased ALMP activity. Both NL and EMS use an expenditure measure to specify the ALMP variable, instrumented to address the endogeneity issue. ${ }^{8}$

Unions and collective bargaining. It is well known that compensation determined under collective bargaining is higher than compensation negotiated individually. It is through this effect on labour costs, then, that unions and collective bargaining can be expected to increase unemployment. However, the structure and process of collective bargaining may influence wage determination and, thus, unemployment. For example, where wage bargaining is centralized or where employers and unions coordinate their bargaining, is the upward pressure on wages and unemployment moderated? NL and EMS use a series of measures to measure these effects including union density, collective bargaining coverage (NL only), and the degree of centralization and coordination in collective bargaining. ${ }^{9}$

Employment protection legislation. This pertains to the regulatory framework governing hiring and firing. Employment protection legislation (EPL) includes regulations governing the use of temporary and fixed contracts, treatment of disadvantaged groups, layoff procedures, severance payments, and so on. The relationship between EPL and unemployment is complex: on the one hand, restrictive rules may impede hiring but, on the other hand, they can support job security, thereby reducing layoffs. NL and EMS measure EPL using an index developed by the OECD (1994) that evaluates the strength of the legal framework.

From the description of the policy and institutional variables, it should be obvious that the advantage of a "big-picture" cross-country overview offered by studies along the lines of NL and EMS does come at a cost. Specifying single measures in these areas cannot fully represent the reality of country situations. In particular, this applies to minimum wages, active labour market programs, employment protection, and collective bargaining where coverage, enforcement, heterogeneity, and institutional detail all add to the complexity involved. Finally, the studies do not take into account interactive effects either between different policies or institutions (e.g., minimum wage laws and collective bargaining) or between policies and institutions, on the one hand, and the macroeconomic environment, on the other. ${ }^{10}$

\section{The Determinants of Structural UNEMPLOYMENT}

The results of the NL and EMS estimations are summarized in Table 2. The contents are based on the calculated coefficients $\left(\beta_{1}\right)$ for the $X_{i t}$ variables in equation (1). For the sake of simplicity, the general direction of the estimations is reported here rather than the coefficients themselves. ${ }^{11}$ A positive (negative) sign indicates that the policy or institution was found to be positively (negatively) associated with the unemployment rate (with the coefficient statistically significant at least at a 10 percent level). A zero indicates that the coefficient was insignificant and an uncertain relationship is represented by a question mark. 
TABLE 2

Unemployment Determinants, OECD Countries, 1983-1994/95

\begin{tabular}{lcc}
\hline & $\begin{array}{c}\text { Nickell and Layard } \\
(1997)\end{array}$ & $\begin{array}{c}\text { Elmeskov et al. } \\
(1998)\end{array}$ \\
\hline Taxes & + & + \\
Minimum wage & $(?)$ & 0 \\
Ul benefits/duration & $+/+$ & + \\
ALMP & - & - \\
EPL & 0 & + \\
Union/CB coverage & $+/+$ & $0 / ?$ \\
Centralization/ & & \\
Coordination & $0 /-$ & hump/- \\
\hline \hline
\end{tabular}

In both studies, taxes were found to be significant determinants of unemployment. The higher the tax level, whether specified by an overall tax rate in the case of NL or a tax wedge in EMS, the higher was the unemployment rate. A closer look at the results, however, suggests qualifications. While NL found that the overall tax rate was positively associated with unemployment, payroll taxes alone had an insignificant effect. Moreover, neither study found that the magnitude of the effect was particularly large.

Only EMS included a separate variable for minimum wages in their estimations. As Table 2 shows, the coefficient for this variable was statistically insignificant. While this supports the argument that the level that minimum wages are set at does not have a significant impact on the aggregate unemployment rate, both EMS and NL have concluded from existing research that youth unemployment does increase with higher levels.

Both NL and EMS find that the generosity of the unemployment insurance system is positively associated with unemployment rates. The measure used by EMS does not allow us to disentangle the separate effects of benefit levels and benefit duration. However, in NL's model, the replacement rate and duration are each statistically significant. When NL estimates the determinants of long-term and shortterm unemployment separately, they find that the replacement rate is a significant factor in short-term unemployment but not long-term unemployment while, not surprisingly, the duration variable only comes through in the latter case.

Both studies find that spending on active labour market programs is negatively associated with unemployment rates. These studies specify this variable differently and the level of significance is higher in NL (using spending as a share of GDP) than in EMS (spending per unemployed worker relative to GDP per capita), which only reaches the 10 percent level. ${ }^{12}$ In the final analysis, it is difficult to interpret the results on active labour market programs. First, there are various measurement problems, including the endogeneity issue noted earlier. Second, in most countries the numbers of participants in these programs tend to be relatively small which raises questions about what magnitude of impact might be expected even if ALMPs are effective. ${ }^{13}$ Finally, their effectiveness is itself a question of policy significance. Existing evidence from scientific evaluations paints a very modest picture of the employment gains attributable to these programs (e.g., OECD 1993). In sum, ALMPs represent an area where future research will be important to consider its potential role in reducing structural unemployment.

Both studies identify significant but somewhat complex relationships involving unions and collective bargaining. NL finds that unionization, both in terms of union density and collective bargaining coverage, is associated with higher unemployment rates. EMS also has the same result with union density when no other collective bargaining variables are entered in the equation. However, once the degree of bargaining coordination and centralization is considered, the impact of unions is not so simple. 
NL finds that a high degree of coordinated bargaining between employers and unions can offset the unemployment effect of unionization. In the EMS estimations, the significant union density coefficient disappears when the bargaining structure variables are introduced. Their analysis also finds that high degrees of centralization and coordination are significantly associated with lower unemployment rates. ${ }^{14}$ However, the EMS results also offer some support for the "hump-shaped" hypothesis (Calmfors and Driffill 1988) which argues that high and low levels of centralization and coordination each have superior labour market impacts compared to systems in the middle. According to this hypothesis, enterprise-level bargaining and centralized/ coordinated bargaining both have checks, albeit very different, that lead to moderate wage outcomes and thus no significant unemployment impacts.

The results regarding employment protection legislation are mixed. Both studies operationalize this variable using an index calculated by the OECD (1994) that evaluates the strictness of hiring and firing rules. NL finds the coefficient insignificant in their aggregate employment model although in their short-term unemployment equation, it is significant and negative. This result is broadly consistent with the hypothesis that strong EPLs inhibit turnover (and therefore short-term unemployment) but increase the incidence of long-term unemployment. ${ }^{15}$ In most of the specifications estimated by EMS, the employment protection variable is positive and significant. NL actually included a more comprehensive labour standards variable in their model which included minimum wages, employee representation rights, and working time, in addition to employment protection rules. This variable had no association with unemployment rates.

Our understanding of the labour market impacts of employment protection legislation has been extended considerably by a recent cross-country analysis undertaken by the OECD (1999). This research has extended earlier studies, including NL and EMS, largely because of an updated and richer database. The OECD's measures include legislation but also attempt to incorporate other sources of regulation stemming from collective bargaining or judicial interpretations, for example. The indicators cover three categories of employment protection related to hiring and firing: for regular employees, for temporary employees, and rules governing collective dismissals.

Table 3 reports the summary EPL measures for a selection of countries. As would be expected, the continental European countries have higher indices, reflecting stronger employment protection rules, than the Anglo-Saxon countries, including Canada. Regulations relating to the deployment of both regular and temporary workers are much weaker in the latter group of countries. This includes various aspects of dismissal in the case of regular employees and the freedom to contract on a fixed-term basis and through temporary agencies for temporary employees. In terms of the third category of EPL, the regulation of collective dismissal, including the definition of a collective dismissal, provision of notice, and required delays, Canada, the United States, and the United Kingdom are comparable to most European countries.

The OECD analysis of the impacts of EPL on labour market performance suggests that the importance of these rules is far less than is commonly believed. Whether the indices reported in Table 3 are entered into the unemployment rate model as a single overall measure or separately for regular and temporary employment and collective dismissals, the estimated coefficients are insignificant. It should be noted that the OECD analysis did find some statistically significant associations between EPL and employment levels and turnover. Stricter protection does seem to lead to lower employment-topopulation ratios, but it is also associated with lower labour force participation rates which explains the insignificant unemployment effect. The estimations also support the hypothesis that stricter EPL is also associated with longer unemployment spells and job duration. In this way, it may contribute to "insider- 
TABLE 3

Summary Indicators of Employment Protection Legislation, Selected OECD Countries, Late 1990s ${ }^{1}$

\begin{tabular}{lcccc}
\hline & Regular Employment & Temporary Employment & Collective Dismissals & Overall Score \\
\hline Canada & 0.9 & 0.3 & 3.4 & 1.1 \\
United States & 0.2 & 0.3 & 2.9 & 0.7 \\
Japan & 2.7 & 2.1 & 1.5 & 2.3 \\
France & 2.3 & 3.6 & 2.1 & 2.8 \\
Germany & 2.8 & 2.3 & 3.1 & 2.6 \\
Sweden & 2.8 & 1.6 & 4.5 & 2.6 \\
Netherlands & 3.1 & 1.2 & 2.8 & 2.2 \\
United Kingdom & 0.8 & 0.3 & 2.9 & 0.9 \\
\hline
\end{tabular}

Note: 1. Higher scores indicate greater strictness in employment protection legislation and interpretation. Scores reported for regular employment, temporary employment, and collective dismissals are summary measures based on scores for disaggregated items. The overall score is a weighted average of the disaggregated measures. Data are based on a variety of sources including information provided by governments, the European Commission and multi-country surveys. For federal states including Canada, scores incorporate information from both national and subnational jurisdictions. For more details, see OECD (1999).

Source: OECD (1999, Table 2.5).

outsider" effects. While the OECD analysis is far from definitive in demonstrating these effects, in those cases where EPL does seem to favour particular segments of the labour force, it is most likely that prime-age males receive the benefits.

In the final analysis, there is still much to learn in the area of labour market regulation. The analysis of the impacts of EPL is largely inconclusive. Moreover, while hiring and firing rules are obviously an important part, the flexibility debate is actually broader, encompassing compensation norms, hours, and other labour standards. We still know very little about how policy in these areas affects employment performance. ${ }^{16}$

\section{Policy Implications}

To summarize, the cross-country evidence presents a mixed picture. Some factors, such as the generos- ity of the unemployment insurance system, are systematically associated with higher levels of unemployment. Others seem to have no impact. Two areas with a lot of profile, taxes and minimum wages, are surprisingly benign in terms of their impacts.

In the final analysis, a variety of different institutional regimes can serve the public policy goal of efficient labour markets. This is clear when we note that the countries with good unemployment records have not followed the same path. Take the United States, Austria, Sweden, and Japan, for example. Compared to Canada, each has had a significantly better unemployment performance in the 1980s and 1990s and each currently has a lower unemployment rate. Yet the institutional models vary. The United States has a relatively deregulated and noninterventionist regime. This is the case in some areas for Japan (e.g., minimal unemployment insurance, low taxes) but not in others (e.g., collective 
bargaining coordination, employment protection legislation). Sweden and Austria are relatively regulated, coordinated, and interventionist across the board. But even in this case, other relatively small, prosperous northern European countries with good unemployment performance (e.g., Netherlands, Norway) seem to have their own formulas.

So what does all of this mean for the labour policymaker in Canada? Unfortunately, the primary lesson is that there is no "low-unemployment" institutional recipe. There may be a "flexibility threshold" that all countries (perhaps with the exception of small northern European ones) must meet. But it would be hard to argue that Canada has not met that standard. The generosity of the unemployment insurance system has been diminished considerably over the past 15 years. The features of the wage bargaining system (relatively low coverage and a decentralized structure), minimum wage levels, taxes, and employment protection legislation are all in line with what the cross-country evidence suggests should be supportive of low unemployment levels.

Certainly, Canadian policymakers need to learn more about precisely how some aspects of regulation, most notably employment protection laws and other labour standards, do affect the performance of the labour market in this country. The interaction between different policies needs more analysis. And the fact that we have multiple jurisdictions for employment regulation should be much more fully exploited by researchers. But, a credible explanation for Canada's disappointing unemployment record must look beyond unemployment insurance, taxes, unions, and labour law.

\section{Notes}

This article is based on a panel presentation made at the Conference on the Structural Aspects of Unemployment in Canada sponsored by the Centre for the Study of Living Standards in Ottawa in April 1999. The views expressed are solely those of the author.
${ }^{1}$ Using the sweeping "European" term is of course misleading since there are great differences in the institutions, policies, and unemployment rates across Europe.

${ }^{2}$ There are other more encompassing issues that stem from the fact that these policies and institutions affect more than just the unemployment rate. Their impact on income distribution and social protection must also be considered by the policymaker, but beyond noting this I will not address these broader considerations.

${ }^{3}$ There are many ways in which structural and cyclical forces interact. This issue has been at the heart of the hysteresis or multiple-equilibria literature that has focused on whether cyclical unemployment eventually is transmitted into a higher level of structural unemployment. Debates about the validity of the NAIRU (non-accelerating inflation rate of unemployment) concept also bring the validity of the structural-cyclical distinction to the fore.

${ }^{4}$ The 20 countries covered by NL are Austria, Belgium, Denmark, Finland, France, Germany (West), Ireland, Italy, Netherlands, Norway, Portugal, Spain, Sweden, Switzerland, United Kingdom, Canada, United States, Japan, Australia, and New Zealand. EMS includes the same group except Switzerland.

${ }^{5}$ The regressions computed by EMS are based on 238 observations (19 countries and 13 years with 9 observations dropped). NL's calculations are based on 40 observations (20 countries and 2 time periods). They chose the six-year averages to smooth out the cycle and year-over-year noise.

${ }^{6}$ In both studies, the rate for Denmark is the national rate. NL also use the national rate for Austria and the US Bureau of Labor Statistics "US concept rate" for Italy. $\mathrm{NL}$ also estimates the determinants of both "long-term" and "short-term" unemployment rates where one-year duration defines long-term unemployment.

${ }^{7}$ The effects in Canada have been well studied. While no consensus conclusion seems to emerge from the literature, it is clear that the unemployment impacts of UI have varied over time (with variations in the generosity of the system) and have not been as large as is popularly believed. For recent evidence, see Cremieux $e t$ al. (1996).

${ }^{8} \mathrm{NL}$ uses total ALMP spending as a percentage of gross domestic product (GDP) while EMS calculates the ALMP 
variable as spending per unemployed worker relative to per capita GDP.

${ }^{9}$ Both NL and EMS measure coordination and centralization using a qualitative index developed by the OECD (1994).

${ }^{10}$ This latter issue is the focus of Blanchard and Wolfers (1999).

${ }^{11}$ The actual calculations are reported in Table 15 in NL and Table 2 in EMS.

${ }^{12}$ However, when EMS runs their model without Sweden (which they argue is an outlier because of its very high level of expenditures on ALMPs), the coefficient becomes statistically significant at the 5 percent level.

${ }^{13}$ For example, according to OECD calculations, the annual inflow into active programs as a proportion of the workforce has been approximately 10 percent in France, 4 to 5 percent in Germany, 3 to 4 percent in Canada, 2 percent in the United Kingdom and the United States, and negligible ( 0.1 percent) in Japan.

${ }^{14}$ The positive impact of high levels of coordinated bargaining on unemployment is also a consistent result of the most recent estimations by the OECD (1999).

${ }^{15}$ In NL's long-term unemployment model, the EPL coefficient is positive but not statistically significant.

${ }^{16}$ In a recent paper, Di Tella and MacCulloch (1999) use qualitative data from executives gathered for the World Competitiveness Report to measure a broad concept of flexibility (i.e., flexibility of enterprises to adjust jobsecurity and compensation standards to economic realities). In an analysis of 21 countries, they find that this interpretive measure of flexibility is associated with increased employment and (less definitively) reduced unemployment.

\section{REFERENCES}

Blanchard, O. and J. Wolfers. 1999. "The Role of Shocks and Institutions in the Rise of European Unemployment: The Aggregate Evidence," unpublished paper available at www.mit.edu/blanchar/www.

Calmfors, L. and J. Driffill. 1988. "Bargaining Structure, Corporatism and Macroeconomic Performance," Economic Policy 6:13-61.

Card, D. and A.B. Krueger. 1997. Myth and Measurement: The New Economics of the Minimum Wage. Princeton, NJ: Princeton University Press.

Cremieux, P.-Y., P. Fortin, P. Storer and M.Van Audenrode. 1996. The Impact of Unemployment Insurance on Wages, Search Intensity, and the Probability of Re-employment. Ottawa: Human Resources Development Canada.

Di Matteo, L. and M. Shannon. 1995. "Payroll Taxation in Canada: An Overview," Canadian Business Economics 3(4):5-22.

Di Tella, R. and R. MacCulloch. 1999. "The Consequences of Labor Market Flexibility: Panel Evidence Based on Suvey Date," unpublished paper available at www.people.hbs.edu/rditella/research.html.

Elmeskov, J., J. Martin and S. Scarpetta. 1998. "Key Lessons for Labour Market Reform: Evidence from OECD Country Experiences," Swedish Economic Policy Review 5(2):205-52.

Neumark, D. 1999. "The Employment Effects of Recent Minimum Wage Increases: Evidence from a Pre-Specified Research Design," NBER Working Paper No. 7171. Cambridge, MA: National Bureau of Economic Research.

Nickell, S. and R. Layard. 1997. "The Labour Market Consequences of Technical and Structural Change," Discussion Paper Series, No. 23. London: Centre for Economic Performance.

Organization for Economic Cooperation and Development (OECD). 1993. Employment Outlook. Paris: OECD. 1994. The Jobs Study. Paris: OECD.

1999. Employment Outlook. Paris: OECD.

Welch, F. 1995. "Myth and Measurement: The New Economics of the Minimum Wage," Industrial and Labor Relations Review 48(4):842-49. 